\title{
Quantifying the Relative Importance of Climate and Habitat on Structuring the Species and Taxonomic Diversity of Aquatic Plants in a Biodiversity Hotspot of Tropical Asia
}

(Mengukur Kepentingan Relatif Iklim dan Habitat Terakhir Penstrukturan Spesies dan Kepelbagaian Taksonomi Tumbuhan Akuatik di Bintik Panas Kepelbagaian Biologi Asia Tropika)

\author{
YOUHUA CHEN*
}

\begin{abstract}
It has not been well known how climate and habitat variables will influence the distribution of plant species to some extents at mesoscales. In this report, by using the distribution of aquatic plants in Western Ghats, a biodiversity hotspot in tropical Asian region, I quantify the relative importance of climate and habitat variables on structuring spatially species richness and taxonomic diversity patterns using structural equation modeling. All the sampling qudrats in the region used for the study has a spatial resolution of 0.5 latitude $\times 0.5$ longitude. The results showed that species richness is high in both northern and southern part of the region, while low in the middle part. In contrast, taxonomic distinctiveness is relatively homogeneous over all the sampling quadrats in the region. Structural equation modeling suggested that taxonomic distinctiveness patterns of aquatic plants in the region follow temperature (partial regression coefficient $=0.31, \mathrm{p}<0.05$ ) and elevational (partial regression coefficient $=0.31, \mathrm{p}<0.05$ ) gradients, while richness patterns cannot be explained by any of the currently used variables. In conclusion, environmental variables that are related to taxonomic distinctiveness would not be related to richness, given the fact that these two quantities are orthogonal more or less. Both climate and habitat are equally influential on taxonomic distinctiveness patterns for aquatic plants in Western Ghats of India.
\end{abstract}

Keywords: Climatic envelope; environmental correlation; Linnaeus classification; WorldClim database

ABSTRAK

Masih belum diketahui bagaimanakah pemboleh ubah iklim dan habitat akan mempengaruhi taburan spesies tumbuhan mengikut skalameso. Dalam laporan ini, dengan menggunakan taburan tumbuhan akuatik di Barat Ghats yang merupakan titik panas kepelbagaian biologi di rantau Asia tropika, saya menentukan kepentingan pemboleh ubah iklim dan habitat terakhir penstrukturan reruang kekayaan spesies dan taksonomi kepelbagaian corak menggunakan pemodelan persamaan struktur. Semua sampel quadrat yang digunakan untuk kajian di rantau ini mempunyai resolusi reruang 0.5 latitud $x$ longitud 0.5. Hasil kajian menunjukkan bahawa kekayaan spesies adalah tinggi di bahagian utara dan selatan rantau ini, manakala rendah di bahagian tengah. Sebaliknya, perbezaan taksonomi adalah agak seragam ke atas semua sampel quadrat di rantau ini. Pemodelan persamaan struktur mencadangkan bahawa pola perbezaan taksonomi tumbuhan akuatik di rantau ini mengikut suhu (pekali regresi separa $=0.31, \mathrm{p}<0.05$ ) dan ketinggian (pekali regresi separa $=$ $0.31, \mathrm{p}<0.05)$ kecerunan, manakala pola kekayaan tidak dapat dijelaskan oleh mana-mana pemboleh ubah yang sedang digunakan. Kesimpulannya, pemboleh ubah alam sekitar yang berkaitan dengan perbezaan taksonomi tidak berkaitan dengan kekayaan, memandangkan kuantiti kedua-duanya adalah lebih atau kurang ortogon. Kedua-dua iklim dan habitat mempengaruhi pola perbezaan taksonomi untuk tumbuhan akuatik di Barat Ghats India.

Kata kunci: Iklim sampul; korelasi alam sekitar; pangkalan data WorldClim; pengelasan Linnaeus

\section{INTRODUCTION}

Biodiversity hotspots are one of the major focuses in ecology (Myers et al. 2000). Many conservation practices are done and ecological questions are addressed on these hotspots (Forest et al. 2007; Huang et al. 2012; Williams et al. 1996). Western Ghats is a mountainous range along the south-western coast of India, which has a rich history and an impressive wildlife array. It has been recognized as one of the biodiversity hotspots of the world (http://wwf. panda.org/what_we_do/where_we_work/western_ghats/). The location and range extent of this biodiversity hotspot is shown in Figure 1(a).

Biodiversity has multiple components. In the present study, only species and taxonomic diversity are the focuses since these two quantities may be easily obtained from species checklist of the studied area. Hereafter, taxonomic diversity is specifically referred to as taxonomic distinctness index (Clarke \& Warwick 2001, 1999, 1998), both terms are 
used interchangeably in this study. Taxonomic diversity has been widely used to quantify the impacts of environmental stress and anthropogenic disturbance on biodiversity in some previous studies (Bevilacque et al. 2012; Leonard et al. 2006; McClanahan et al. 2011; Pavao-Zuckerman \& Coleman 2007; Pienkowski et al. 1998; Wang \& Chen 2009). Because taxonomic distinctness index is believed to be insensitive to species richness (Clarke \& Warwick 2001, $1999,1998)$, it is easily predicted that those explanatory variables most correlated with species richness should be least correlated with taxonomic distinctness, vice versa. In the present study, one of the central aims was to test this simple hypothesis using tropical plants as the study model. The relative importance of different categories of ecological variables on patterning community structure is a recent advance in the field of ecology community. In general, the relative importance of dispersal limitation and environmental filtering is the major focus in current literature (Borcard et al. 1992; Legendre 2007; Legendre et al. 2009; Lindo \& Winchester 2009). However, it has not been well known how climate and habitat variables will influence the distribution of plant species to some extents at mesoscales. If such kinds of studies have been published, very likely they focused on global- and continental- species richness patterns. In the present study, as another central goal, the author systematically compare and quantify the relative contribution of climate and habitat variables on structuring the distribution of 286 aquatic plants in Western Ghats, a biodiversity hotspot in South Asia and the world.

\section{MATERIALS AND METHODS}

\section{DISTRIBUTION OF AQUATIC PLANTS}

The distribution of 286 aquatic plants in the region of Western Ghats in India was obtained from Indian Biodiversity Portal (http://www.indiabiodiversity.org) including species name, distributional records and record source.

\section{SPECIES DIVERSITY FOR SAMPLING QUADRATS}

The number of species presented in each of the sampling grid was counted. In the present study, each sampling grid was fixed to have the spatial size of 0.5 latitude $x$ 0.5 longitude (around $3136 \mathrm{~km}^{2}$ ) over the whole area of Western Ghats, India. In a total, 83 sampling quadrats were used for the present study, covering an area with size around 26 million ha.

\section{TAXONOMIC DIVERSITY FOR SAMPLING QUADRATS}

The taxonomic distinctiveness index developed by previous studies (Clarke \& Warwick 2001, 1999, 1998) for each of the 83 sampling quadrats was calculated. For each species, Linnaeus classification following a way as order, family, genus and species was employed. The Catalogue of Life online database (http://www.catalogueoflife.org) was used to search the taxonomic classification of each species. The $\Delta^{+}$index (Clarke \& Warwick 1998) was utilized since it is suitable for presence/absence data, which reads,

$$
\Delta^{+}=\left\{\sum \sum_{i<j} \omega_{i j}\right\} /\{S(S-1) / 2\}
$$

Here, $s$ is the number of species present in the taxonomic classification tree, $\omega_{i j}$ is the distinctness weight given to the path length linking species $i$ and $j$ in the classification tree. One simple weight is that $\omega_{i j}$ is equal to the number of internal nodes for linking the two species.

\section{CLIMATIC VARIABLES}

Related climatic data were collected using WorldClim database (http://www.worldclim.org). All the 19 bioclimatic variables (bio1...bio19: full names are listed in Appendix I) were used. To avoid collinearity and the removal of influence for unimportant variables, a principal component analysis (PCA) was utilized to choose the first two major axes representing the principal information hidden in all these 19 bioclimatic variables for subsequent analyses (denoted as CPC1 and CPC2, respectively).

\section{HABITAT VARIABLES}

The following variable were considered for the region of Western Ghats: elevation (EL), vegetation type (VT), soil carbon (SC), forest type (FT) and minimum distance from each sampling quadrat to the river (D2R); minimum distance from each sampling quadrat to the dam (D2D) and watershed classification (WS). Most of these habitat variables were directly collected from the Indian Biodiversity Portal (http://www.indiabiodiversity.org), while some of them had to be recalculated. For example, D2D was calculated on the basis of dam distribution map in the region while D2R was calculated on the basis of river distribution map in the region. In the present study, for speeding up computation, D2D was approximated as the minimal distance from the center of a sampling quadrat to the vertex of the boundary polygon of a dam. As above, to avoid collinearity and removal of unimportant variables, PCA was applied to choose the first two axes (denoted as HPC1 and HPC2, respectively).

\section{STRUCTURAL EQUATION MODELING}

Structural equation modeling (Arhonditsis et al. 2006; He 2013; Lam \& Maguire 2012) was used to build the connections between ecological variables and species and taxonomic diversity patterns all over the sampling quadrats. The hypothetical relationships among covariates and response variables were built on the basis of the logics used in some previous studies (Qian \& Kissling 2010; Qian et al. 2009) as presented in Figure 1(b). The 'lavaan' package (Rosseel 2012) was utilized to fit the structural equation models under $\mathrm{R}$ environment ( $\mathrm{R}$ Development Core Team 2013). 
(a)

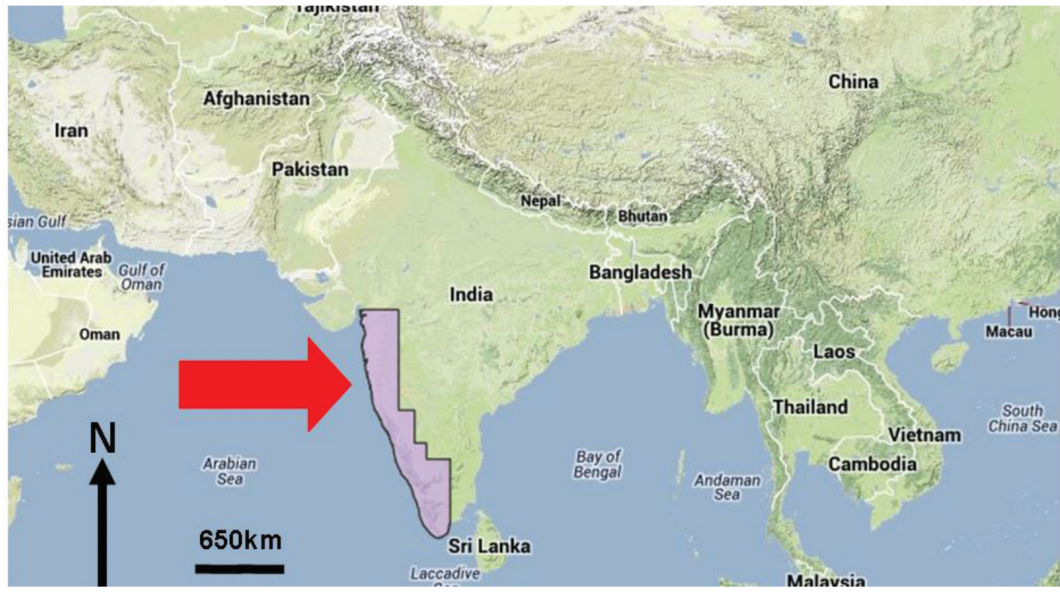

(b)

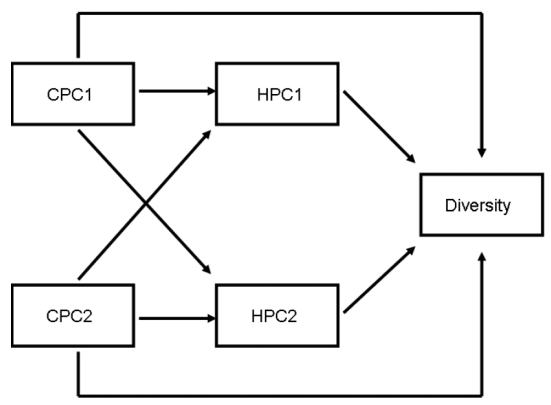

FIGURE 1. Range extent of the study area of Western Ghats in tropical Asia (indicated by the red arrow) (a) and the corresponding logic flow chart for showing the interactions and directions among variables for structural equation modeling

(b). CPC1 and CPC2 denote the first two axes of PCA for the nineteen bioclimatic variables, while HPC1 and HPC2 denote the first two axes of PCA for the seven habitat variables

\section{RESULTS}

\section{SPECIES AND TAXONOMIC DIVERSITY MAPPING}

As shown in Figure 2(a), high plant richness grids were located in both northern and southern parts of Western Ghats. In contrast, in the middle latitudinal range of the region, plant species richness was relatively low. However, for spatial taxonomic diversity patterns, most grids had relatively similar $\Delta^{+}$values (Figure 2(b)). For grids in the middle latitudinal range of the region, they still had similar $\Delta^{+}$as those in the northern and southern parts of the region. Thus, taxonomic diversity $\Delta^{+}$of aquatic plants in Western Ghats has relatively homogenous spatial patterns.

\section{FEATURES OF CLIMATIC AND HABITAT GRADIENTS FOR THE DISTRIBUTION OF PLANTS}

CPC1 was most correlated to bio8, bio9 and bio1, while CPC2 was most associated with bio19, bio15 and bio10 (Table 1). All the three top variables, bio8, bio9 and bio1, were temperature-associated, while both bio19 and 15 were precipitation-related variables (see the corresponding full names for these abbreviations in Appendix I). Thus, $\mathrm{CPC} 1$ represents the temperature gradient, while $\mathrm{CPC} 2$ represents the precipitation gradient structuring the distribution and diversity patterns of aquatic plants in Western Ghats.

The most influential variable characterizing HPC1 was Ws, followed by FT and VT (Table 2). In contrast, the most correlated variable characterizing HPC2 was EL, followed by D2D and SC. As such, HPC1 indicates the forest and vegetation classification of the sampling grids, while HPC2 represents the elevational gradient for the distribution and diversity patterns of aquatic plants in Western Ghats.

\section{THE CORRELATION BETWEEN CLIMATIC AND HABITAT VARIABLES}

As suggested by the standardized partial regression coefficients, both HPC1 and HPC2 were most related to CPC1 (Figure 3). Thus, temperature gradient is a principal driver for the habitat gradient in the region, precipitation gradient seems less influential. The signs of the partial regression coefficients imply the logical relationship between habitat and climatic gradients. For example, for HPC2, the standardized partial regression coefficient was -0.52 with significant support $(p<0.05)$ (Figure 3$)$. It should indicate that the temperature would decrease (indicated by CPC1) along with the elevational gradient from low to high altitudes (represented by HPC2).

For HPC1, the partial regression coefficient was $-0.46(p<0.05)$ (Figure 3$)$. It should imply that in lower- 
(a)

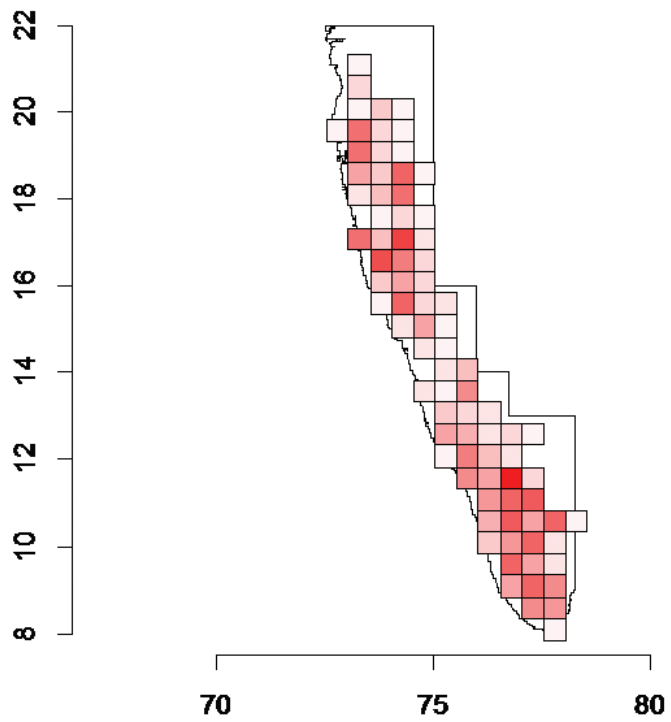

(b)

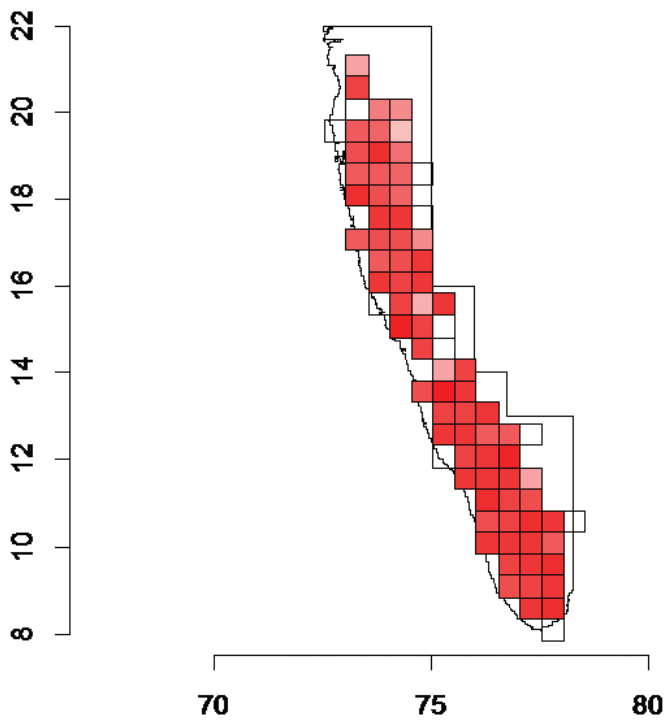

FIGURE 2. Species and taxonomic diversity pattern of aquatic plants in Western Ghats, India. (a) species richness and (b) taxonomic distinctiveness $\Delta^{+}$. Colors from red to white indicate diversity values from high to low

TABLE 1. Correlation between each climatic variable with the first two principal axes of PCA. For each axis (in columns), numeric values in bold face indicate the top- 3 most correlated bioclimatic variables with that PCA axis. Full names for these 19 variables can be found in Appendix I

\begin{tabular}{ccc}
\hline & CPC1 & CPC2 \\
\hline bio1 & $\mathbf{- 0 . 9 2 1}$ & 0.314 \\
bio2 & -0.762 & -0.139 \\
bio3 & 0.698 & 0.496 \\
bio4 & -0.067 & 0.071 \\
bio5 & -0.17 & -0.018 \\
bio6 & 0.825 & -0.058 \\
bio7 & -0.777 & -0.252 \\
bio8 & $\mathbf{- 0 . 9 3 8}$ & 0.276 \\
bio9 & $\mathbf{- 0 . 9 1 6}$ & -0.298 \\
bio10 & -0.18 & $\mathbf{0 . 6 1 1}$ \\
bio11 & -0.863 & -0.289 \\
bio12 & 0.056 & 0.106 \\
bio13 & 0.016 & 0.101 \\
bio14 & 0.306 & 0.479 \\
bio15 & -0.112 & $\mathbf{- 0 . 6 1 1}$ \\
bio16 & -0.062 & 0.354 \\
bio17 & 0.318 & 0.524 \\
bio18 & -0.162 & -0.14 \\
bio19 & 0.229 & $\mathbf{0 . 6 4 6}$ \\
\hline
\end{tabular}

temperature areas (mountainous or high-elevation region), the vegetation types would be reduced, while forest and watershed types vary greatly.
TABLE 2. Correlation between each habitat variable with the first two principal axes of PCA. Abbreviations: elevation (EL), vegetation type (VT), soil carbon (SC), forest type (FT), minimum distance from each sampling quadrat to the river (D2R), minimum distance from each sampling quadrat to the dam (D2D) and watershed classification (WS)

\begin{tabular}{lcc}
\hline & HPC1 & HPC2 \\
\hline VT & $\mathbf{0 . 3 3 4}$ & 0.146 \\
WS & $\mathbf{- 0 . 9 9 9}$ & 0.039 \\
D2D & -0.063 & $\mathbf{- 0 . 5 0 5}$ \\
D2R & 0.068 & -0.16 \\
FT & $\mathbf{- 0 . 3 7 1}$ & -0.087 \\
SC & 0.09 & $\mathbf{0 . 2 5 7}$ \\
EL & 0.142 & $\mathbf{0 . 9 8 9}$ \\
\hline
\end{tabular}

\section{RELATIVE IMPORTANCE OF HABITAT AND CLIMATE ON STRUCTURING SPECIES RICHNESS AND TAXONOMIC DISTINCTIVENESS PATTERNS OF AQUATIC PLANTS}

As showed in Figure 3(a), for species richness, neither climate nor habitat plays important roles because the standardized partial regression coefficients for the direct effects linking species richness and habitat/climate variables were all insignificant. In contrast, for taxonomic distinctiveness (Figure 3(b)), both climate and habitat are equally important, as evidenced by the significant partial regression coefficients for the arrows linking HPC2 and CPC1 to TaxDiv. Both direct effects (HPC2->TaxDiv; CPC1$>$ TaxDiv) had a coefficient $0.31(p<0.05)$.

\section{DISCUSSION}

In the transition zone of the region (middle latitudinal range), the diversity $\Delta^{+}$values for the sampling grids were 
(a)

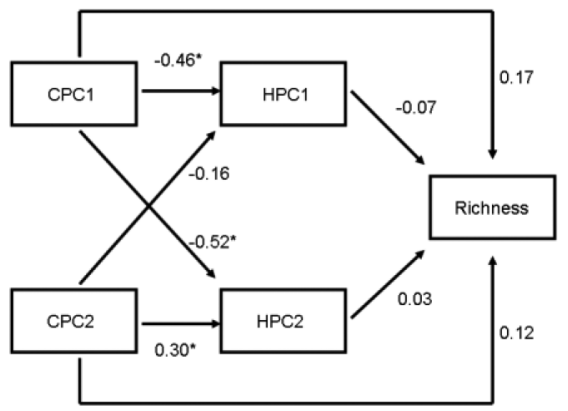

(b)

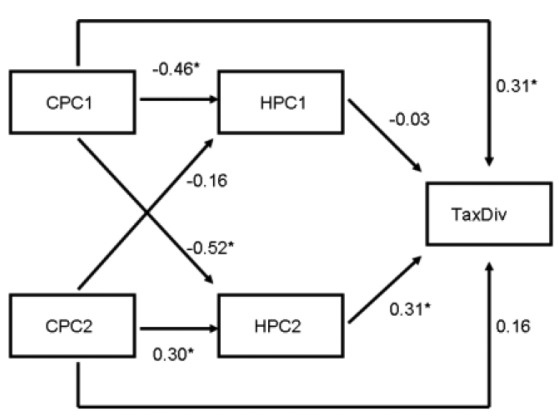

FIGURE 3. Fitted structural equation models for both species richness (a) and taxonomic distinctiveness (b) Numeric values on the arrows are standardized partial regression coefficients. Asterisks indicate significant coefficients at the level of 0.05 . CPC1 and

CPC2 denote the first two axes of PCA for the nineteen bioclimatic variables; while HPC1 and HPC2 denote the first two axes of PCA for the seven habitat variables. TaxDiv denotes the taxonomic distinctiveness index

as high or similar as those grids situated at the northern or southern part of the region (Figure 1(b)). One reason for such a homogenous $\Delta^{+}$pattern is that it is unrelated to species richness to a great extent (Clarke \& Warwick 2001, 1999, 1998).

Through structural equation modeling, the present results implied that species richness patterns of aquatic plants cannot be explained by either bioclimatic or habitat variables used at present. However, taxonomic distinctiveness patterns of aquatic plants in Western Ghats of India are jointly determined by temperature and elevational gradients (Figure 3(b)). Thus, these results support the abovementioned hypothesis in a weak term: Environmental variables that cannot explain species richness may be able to explain taxonomic diversity patterns since taxonomic distinctiveness is insensitive to species richness.

For the implications of future studies, there are multifaceted opening research topics, i.e. the relationship between plant and animal richness patterns (Qian 2007) in the region, the impact of fire history and forest type on structuring species community compositional patterns (Reich et al. 2001), the evaluation on the effectiveness of the currently established conservation corridors (Haddad 2008; Lindenmayer \& Nix 1993) or relevant discussion on the potential corridors adapted to future climate change (Beier 2012).

Taxonomic diversity might serve as a shortcut (Keith et al. 2005; Perez-Losada \& Crandall 2003; Schweiger et al. 2008) to evaluate the influence of evolutionary history among lineages on structuring contemporary community structure of species because taxonomic affinity among species is a reflection of evolutionary interaction between species. In the present report, the spatial taxonomic diversity patterns for aquatic plants in Western Ghats of India were correlated with temperature and elevation (Figure 3). Based on the prediction of phylogenetic niche conservatism hypothesis (Liu et al. 2012; Losos 2008; Wiens 2004), temperature and elevation are important factors correlated with the evolutionary time of species, which states that species with relatively old evolutionary age should be the ones with the distributional ranges mainly distributed over the equators/warm areas (Qian 2014). This is because in ancient time, global species mainly distributed in low elevational areas with high temperature (e.g. equators). In this study, taxonomic diversity was calculated based on (1) implied that clade age among species was positively related to the computed taxonomic diversity metric $\Delta^{+}$(because $\omega_{i j}$ is equal to the number of internal nodes for linking the two species, given a clade of species, when the age for this clade is older, the weight $\omega_{i j}$ will become higher). Thus, there should be positive associations between taxonomic diversity, mean temperature condition and latitudinal range extent across the species ranges. Based on the present results using structural equation modeling (Figure 3 ), it is found that one of the above two predictions was supported but another was not supported. As seen in Figure 3, the partial regression coefficient between $\mathrm{CPC} 1$ and TaxDiv was a significant positive value $0.31(p<0.05)$. However, CPC1 was negatively and significantly correlated with bio1 (annual mean temperature, Table 1 and Appendix I). Thus, the indirect association between annual mean temperature and taxonomic diversity should be negative, being contradictory to the above hypothesis between taxonomic diversity and temperature. In contrast, HPC2 was positively and significantly related to elevation (Table 2) and it has a positive and significant partial regression coefficient 0.31 with TaxDiv (Figure 3). Such an observation indicates that the indirect correlation between elevation and taxonomic diversity of aquatic plants in Western Ghats is positive, being consistent with the primary hypothesis.

\section{ACKNOWLEDGEMENTS}

I thank the anonymous reviewer for insightful comments. This work was supported by the China Scholarship Council.

\section{REFERENCES}

Arhonditsis, G., Stow, C., Steinberg, L., Kenney, M., Lathrop, R., McBride, S. \& Recknow, K. 2006. Exploring ecological patterns with structural equation modeling and Bayesian analysis. Ecological Modelling 192: 385-409. 
Beier, P. 2012. Conceptualizing and designing corridors for climate change. Ecological Restoration 30: 312-319.

Bevilacque, S., Sandulli, R., Plicanti, A. \& Terlizzi, A. 2012. Taxonomic distinctness in Mediterranean marine nematodes and its relevance for environmental impact assessment. Marine Pollution Bulletin 64: 1409-1416.

Borcard, D., Legendre, P. \& Drapeau, P. 1992. Partialling out the spatial component of ecological variation. Ecology 73: 1045.

Clarke, K. \& Warwick, R. 2001. A further biodiversity index applicable to species lists: Variation in taxonomic distinctness. Marine Ecology Progress Series 216: 265-278.

Clarke, K. \& Warwick, R. 1999. The taxonomic distinctness measure of biodiversity: Weighting of step lengths between hierarchical levels. Marine Ecology Progress Series 184: 21-29.

Clarke, K. \& Warwick, R. 1998. A taxonomic distinctness index and its statistical properties. Journal of Applied Ecology 35: 523-531.

Forest, F., Grenyer, R., Rouget, M., Davies, T.J., Cowling, R.M., Faith, D.P., Balmford, A., Manning, J.C., Procheş, S., van der Bank, M., Reeves, G., Hedderson, T.A.J. \& Savolainen, V. 2007. Preserving the evolutionary potential of floras in biodiversity hotspots. Nature 445: 757-760.

Haddad, N. 2008. Finding the corridor more traveled. PNAS 105: 19569-19570.

He, T. 2013. Structural equation modelling analysis of evolutionary and ecological patterns in Australian Banksia. Population Ecology 55: 461-467.

Huang, J., Chen, B., Liu, C., Lai, J., Zhang, J. \& Ma, K. 2012. Identifying hotspots of endmeic woody seed plant diversity in China. Diversity and Distributions 18: 673-688.

Keith, M., Chimimba, C., Reyers, B. \& van Jaarsveld, A. 2005. Taxonomic and phylogenetic distinctiveness in regional conservation assessments: A case study based on extant South African Chiroptera and Carnivora. Animal Conservation 8: 279-288.

Lam, T. \& Maguire, D. 2012. Structural equation modeling: Theory and applications in forest management. International Journal of Forestry Research 2012: 263953.

Legendre, P. 2007. Studying beta diversity: Ecological variation partitioning by multiple regression and canonical analysis. Journal of Plant Ecology 1: 3-8.

Legendre, P., Mi, X., Ren, H., Ma, K., Yu, M., Sun, I.F. \& He, F. 2009. Partitioning beta diversity in a subtropical broad-leaved forest of China. Ecology 90: 663-674.

Leonard, D., Clarke, K., Somerfield, P. \& Warwick, R. 2006. The application of an indicator based on taxonomic distinctness for UK marine biodiversity assessments. Journal of Environment Management 78: 52-62.

Lindenmayer, D. \& Nix, H. 1993. Ecological principles for the design of wildlife corridors. Conservation Biology 7: 627-631.

Lindo, Z. \& Winchester, N.N. 2009. Spatial and environmental factors contributing to patterns in arboreal and terrestrial oribatid mite diversity across spatial scales. Oecologia 160: 817-25.

Liu, H., Edwards, E., Freckleton, R. \& Osborne, C. 2012. Phylogenetic niche conservatism in $\mathrm{C} 4$ grasses. Oecologia 170: 835-845.

Losos, J. 2008. Phylogenetic niche conservatism, phylogenetic signal and the relationship between phylogenetic relatedness and ecological similarity among species. Ecology Letters 11: 995-1003.
McClanahan, T., Maina, J. \& Muthiga, N. 2011. Associations between climate stress and coral reef diversity in the western Indian Ocean. Global Change Biology 17: 2023-2032.

Myers, N., Mittermeier, R., Mittermeier, C., da Fonseca, G. \& Kent, J. 2000. Biodiversity hotspots for conservation priorities. Nature 403: 853-858.

Pavao-Zuckerman, M. \& Coleman, D. 2007. Urbanization alters the functional composition, but not taxonomic diversity, of the soil nematode community. Applied Soil Ecology 35: 329-339.

Perez-Losada, M. \& Crandall, A. 2003. Can taxonomic richness be used as a surrogate for phylogenetic distinctness indices for ranking areas for conservation? Animal Biodiversity and Conservation 26: 77-84.

Pienkowski, M., Watkinson, A., Kerby, G., Warwick, R. \& Clarke, K. 1998. Taxonomic distinctness and environment assessment. Journal of Applied Ecology 35: 532-543.

Qian, H. 2014. Contrasting relationships between clade age and temperature along latitudinal versus elevational gradients for woody angiosperms in forests of South America. Journal of Vegetation Science: DOI: 10.1111/jvs.12175.

Qian, H. 2007. Relationships between plant and animal species richness at a regional scale in China. Conservation Biology 21: 937-944.

Qian, H. \& Kissling, W. 2010. Spatial scale and cross-taxon congruence of terrestrial vertebrate and vascular plant species richness in China. Ecology 91: 1172-1183.

Qian, H., Kissling, W., Wang, X. \& Andrews, P. 2009. Effects of woody plant species richness on mammal species richness in southern Africa. Journal of Biogeography 36: 1685-1697.

R Development Core Team. 2013. R: A Language and Environment for Statistical Computing, Vienna, Austria. ISBN 3-900051-07-0, URL http://www.R-project.org.

Reich, P., Bakken, P., Carlson, D., Frelich, L., Friedman, S. \& Grigal, D. 2001. Influence of logging, fire, and forest type on biodiversity and productivity in southern boreal forests. Ecology 82: 2731-2748.

Rosseel, Y. 2012. lavaan: An R package for structural equation modeling. Journal of Statistical Software 48: 1-36.

Schweiger, O., Klotz, S., Durka, W. \& Kuhn, I. 2008. A comparative test of phylogenetic diversity indices. Oecologia 157: 485-495.

Wang, Z. \& Chen, Y. 2009. Relationship between taxonomic distinctness and environmental stress in terrestrial organisms at large spatial scale: A study for insect family Ceratopogonidae in East Asia. Acta Zoologica Bulgarica 61: 69-77.

Wiens, J. 2004. Speciation and ecology revisited: Phylogenetic niche conservatism and the origin of species. Evolution 58: 193-197.

Williams, P., Gibbons, D., Margules, C., Rebelo, A., Humphries, C. \& Pressey, R. 1996. A comparison of richness hotspots, rarity hotspots, and complementary areas for conserving diversity of British birds. Conservation Biology 10: 155-174.

Department of Renewable Resources

University of Alberta, Edmonton, T6G 2H1

Canada

*Corresponding author; email: youhua@ualberta.ca

Received: 13 February 2014

Accepted: 3 July 2014 
APPENDIX I. The full names for all the 19 bioclimatic variables

\begin{tabular}{ll}
\hline bio1 & Annual Mean Temperature \\
bio2 & Mean Diurnal Range (Mean of monthly (max temp - min temp)) \\
bio3 & Isothermality (bio2/bio7) (*100) \\
bio4 & Temperature Seasonality (standard deviation *100) \\
bio5 & Max Temperature of Warmest Month \\
bio6 & Min Temperature of Coldest Month \\
bio7 & Temperature Annual Range (bio5-bio6) \\
bio8 & Mean Temperature of Wettest Quarter \\
bio9 & Mean Temperature of Driest Quarter \\
bio10 & Mean Temperature of Warmest Quarter \\
bio11 & Mean Temperature of Coldest Quarter \\
bio12 & Annual Precipitation \\
bio13 & Precipitation of Wettest Month \\
bio14 & Precipitation of Driest Month \\
bio15 & Precipitation Seasonality (Coefficient of Variation) \\
bio16 & Precipitation of Wettest Quarter \\
bio17 & Precipitation of Driest Quarter \\
bio18 & Precipitation of Warmest Quarter \\
bio19 & Precipitation of Coldest Quarter \\
\hline
\end{tabular}

